Int. J. Morphol.,

32(3):942-949, 2014.

\title{
End-To-Side Loop Neurorrhaphy: Axonal Comparative Stereological Study
}

\author{
Neurorrafia de Blucle Termino-Lateral: Estudio Axonal Estereológico Comparativo \\ Nagib Pezati Boer*; Fausto Viterbo**; Humberto Regis Faleiros ${ }^{* * *}$; Fernando Batigalia ${ }^{* * * *}$; \\ Ana Luísa Ricci Boer****** \& Altair Antonio Carvalho Jr.******
}

BOER, N. P.; VITERBO, F.; FAleiros, H. R.; BATIGAliA, F.; BOER, A. L. R.; CARVALHO Jr., A. A. End-to-side loop Neurorrhaphy: axonal comparative stereological study. Int. J. Morphol., 32(3):942-949, 2014.

SUMMARY: Accidents or diseases can affect the peripheral part of the nervous system, which raises clinical and surgical therapies, among others. In this context, the technique of end-to-side neurorrhaphy is a treatment option, yet its modification loop needs some additional efficacy studies. The purpose of this study was to compare, among rats, stereological results (axons volume density) after end-to-side neurorrhaphy and after end-to-side loop neurorrhaphy. Thirty Wistar rats were used, divided into six groups (five animals per group), consisting of two control groups (for the fibular and tibial nerves), two study groups for the fibular nerve (one with an end-to-side neurorrhaphy, and the other with an end-to-side loop neurorrhaphy) and two study groups for the tibial nerve (with an endto-side neurorrhaphy and the other one with an end-to-side loop neurorrhaphy). After 180 days, all groups were sacrificed for axonal stereological analysis (volume density) in distal nerve stumps. There was significant maintenance of neuronal-axonal density in the distal stumps to neurorrhaphy $(\mathrm{p}<0.005)$ compared with the normal stumps. The end-to-side loop neurorrhaphy is a therapeutic option as suture technique after complete nerve section, in order to restore most of the axonal functional integrity.

KEY WORDS: Nerve; Axon; Stereology; Neurorrhaphy.

\section{INTRODUCTION}

The broader understanding of anatomophysiology of nerve regeneration has provided significant advance in functional outcomes by improving surgical techniques in recent years, strictly related to the axons integrity, Schwann cells (or neurolemmocytes) and the basement membrane of peripheral nerves (Bertelli \& Mira, 1993; Lech, 1990).

When a peripheral nerve is sectioned, the molecular changes start and affect the central and peripheral cells (Calder \& Green, 1995). The distal stump of the injured axon disintegrates and undergoes Wallerian degeneration, and the action of proteolytic enzymes present in the axoplasm desintegrates neurofilaments and microtubules, whilst the rest of the axon is digested by macrophages.

After nerve section, there is also induction of increased mitotic activity of Schwann cells and proliferation of surface receptors of neuronal growth factor (or NGF), which constitute the columns of Bugner. These structures help the growth of nerve sprouts that are formed in the proximal stump of the injured axon, traversing the area of injury and cause a growth cone that determines the direction of the nerve growth Lundborg.

In the functional process of nerve repair, consecutively, the axons overlap between the plasma membrane of Schwann cells and the corresponding basement membrane and form the myelin sheath. At the same time, there is a reorganization of coatings of nerves tracts (epineurium, perineurium and endoneurium), as well as in the blood vessels, in order to restore local homeostasis.

Following the nerve trunk lesions, the peripheral fibers have a daily regeneration speed of $1 \mathrm{~mm}$, depending

\footnotetext{
* Doutor em Ciências da Saúde. Professor titular de anatomia e coordenador do curso de odontologia, Universidade Camilo Castelo Branco, São Paulo, Brazil.

** Livre Docência, Faculdade de Medicina de Botucatu, Universidade Estadual Paulista Júlio de Mesquita Filho - UNESP, São Paulo, Brazil.

*** Mestre em Medicina. Professor titular da disciplina de cirurgia plástica na Universidade Camilo Castelo Branco, São Paulo, Brazil.

***** Doutor em Ciências da Saúde Chefe da disciplina de anatomia clínica na FAMERP é Presidente do Comitê de Ética em Pesquisa em Seres Humanos. Professor e Orientador no Programa de Pós-Graduação Stricto Sensu (foco temático em Anatomia Humana), FAMERP, São Paulo, Brazil.

******Acadêmica de Medicina, Universidade Camilo Castelo Branco, São Paulo, Brazil.
} 
on neurophysiological and surgical factors. The probability of success for axonal growth depends on the length of the gap, which is space among the nerve stumps, caused by nerve injury. The surgical re-approximation of the nerve stumps is called neurorrhaphy.

The first descriptions of the neurorrhaphy was related to the alignment of the axonal conduits by direct suture of the injured stumps (or end-to-side neurorrhaphy). Viterbo (2003) in the nineteenth century. In the same century, another surgical option was to make the distal stump of a nearby intact nerve available to be sutured in a perpendicular direction to the injured nerve (or end-toside neurorrhaphy), initially used in cases of hemifacial spasm or painful neuromas. Another alternative of repairing the end-to-side technique was created, which was called latero-lateral neurorrhaphy (or approximation with the suture of the lateral faces of two nerves) (Amr et al., 1996).

However, initial attempts to induce axonal growth by means of neurorrhaphy techniques have produced disappointing outcomes, which minimized its express indication for nearly a century (Hata, 2000). On the other hand, in the early 1990s, comparative electrophysiological experimental studies have demonstrated muscle reinnervation after end-to-side neurorrhaphy, which led to resurgence of interest in this technique, as well as the development of new surgical options (Flores, 2006). Thus, the crossover neurorrhaphy techniques emerged (or the use of contralateral nerve as a source of axonal donor) (Viterbo, 1993; Flores; Kakibushi et al., 2004) and loop neurorrhaphy (end-to-side suture after total circular involvement of the injured nerve trunk).

Since the improvement of microsurgical techniques has proven essential for the rehabilitation of injured nerves 3 and ideas related to the use of adjacent healthy nerves have aroused great interest among, the purpose of this present study is to compare stereological results (axons volume density) after end-to-side neurorrhaphy and after end-to-side loop neurorrhaphy in rats.

\section{MATERIAL AND METHOD}

After approval by the Ethics Committee, 40 male Wistar rats were studied, all of them from albinus variety, weighing between 200 and $250 \mathrm{~g}$ with an average of 20 weeks of age. The animals were provided by the Central Animal Laboratory of the Paulista State University (UNESP), at Botucatu campus, Brazil.
Anesthesia was induced by intraperitoneal injection of pentobarbital $(30 \mathrm{mg} / \mathrm{kg})$ and, later, the rats were ventrally positioned. After trichotomy in the posterior side of the right hind limb, a $4 \mathrm{~cm}$ incision was made composed of skin, SCT and the adjacent muscle to expose the right sciatic nerve and its fibular, tibial and sural branches. The procedure was performed under surgical DF Vasconcelos microscope with 10x magnifications, and neurorrhaphy were performed with mono nylon 10.0.

The 40 rats were divided into four distinct groups of ten rats each as follows:

Group 1 (normal control group). The sciatic nerve and its fibular and tibial branches were exposed, but they were kept intact and the incision was sutured by planes again. This group represented the normal control of tibial and fibular nerves (Fig. 1).

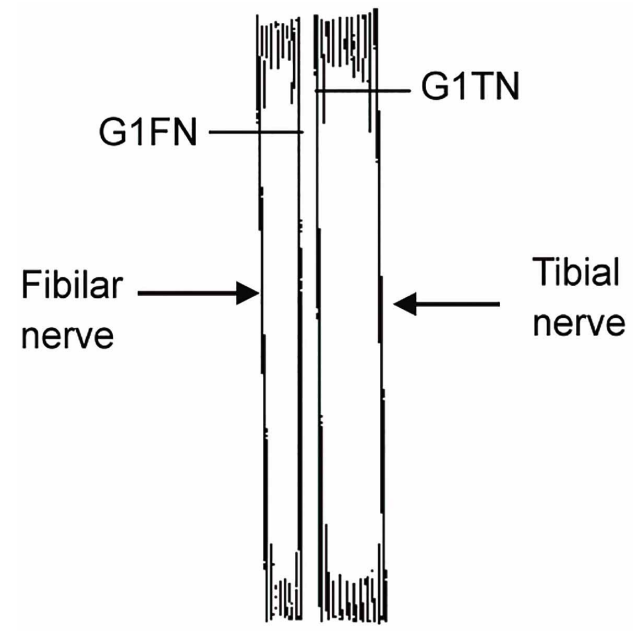

Fig. 1. Normality control. Skin, SCT and muscles were incised and then sutured again.

Group 2 (control group of fibular nerve denervation). The sciatic nerve and its tibial and fibular branches were exposed. The fibular nerve was sectioned and its proximal and distal stumps were sutured in different and distant muscular groups through a nylon 6.0 single stitch. The tibial nerve remained intact. This group represented the control group of the fibular nerve denervation (Fig. 2).

Group 3 (end-to-side neurorrhaphy). The fibular nerve was sectioned and its proximal stump was buried inside the adjacent musculature through a nylon 6.0 single stitch. The distal stump extremity was sutured to the tibial nerve by end-to-side suture with three mono nylon 10.0 simple stitches, without removing the epineurium (end-to-side neurorrhaphy, Fig. 3). 


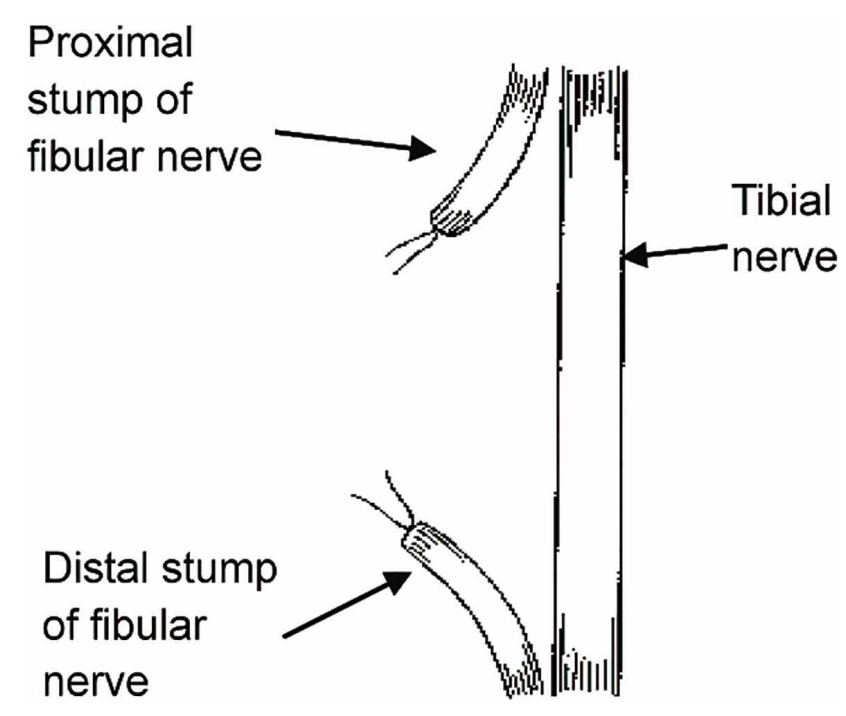

Fig. 2. Control of the fibular nerve denervation. The fibular nerve was sectioned and its proximal and distal stumps were sutured in different and distant muscular groups by a nylon 6.0 single stitch. The tibial nerve remained intact.

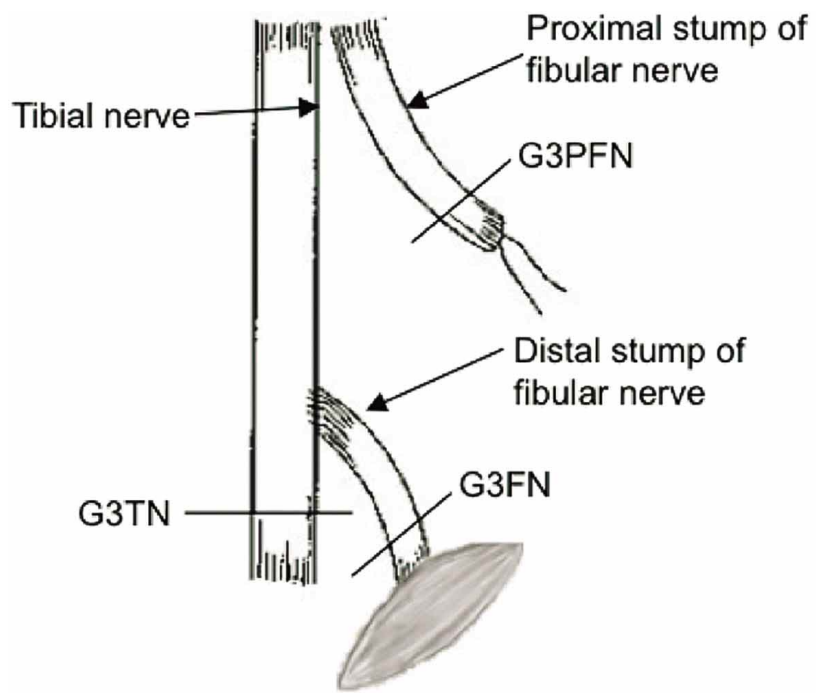

Fig. 3. End-to-side neurorrhaphy. The fibular nerve was sectioned and its proximal stump was buried inside the adjacent musculature by a nylon 6.0 single stitch. The distal stump extremity was sutured to the tibial nerve by end-to-side suture with three mono nylon 10.0 simple stitches, without removing the epineurium.

Group 4 (end-to-side loop neurorrhaphy). The fibular nerve was sectioned and its proximal stump was buried inside the adjacent musculature by a nylon 6.0 single stitch. The distal stump completely wrapped round the tibial nerve and then the stump was sutured to itself with three mono nylon 10.0 simple stitches (End-to-side loop neurorrhaphy, Fig. 4).

After the surgical procedures, the rats remained in appropriate cages and received commercial rat diet and ad

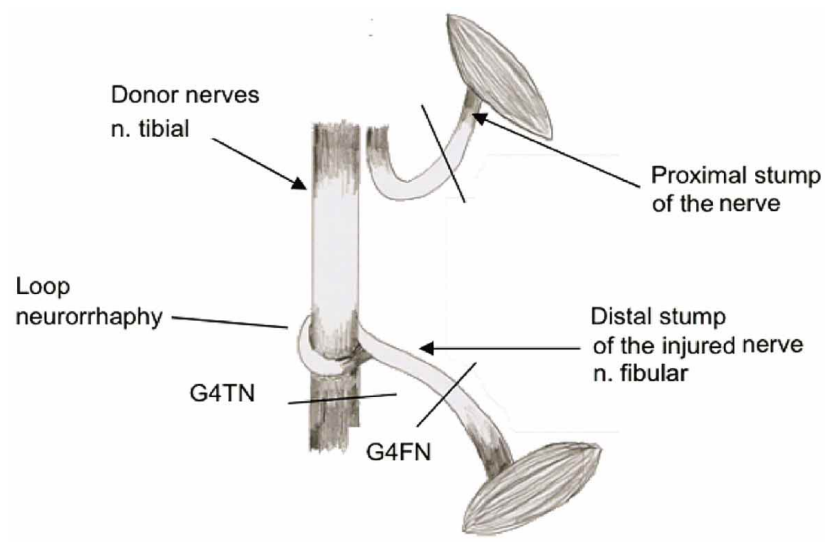

Fig. 4. Schematic drawing of the proposed latero-lateral loop neurorrhaphy. The fibular nerve was sectioned and its proximal stump was buried inside the adjacent musculature by a nylon 6.0 single stitch. The distal stump completely wrapped round the tibial nerve and then the stump was sutured to itself with three mono nylon 10.0 simple stitches.

libitum water during an interval of six months, then they were sacrificed by excessive use of anesthetic and nerve fragments were collected for the study above, as described below.

Histostereological study. The cranial tibial muscles (innervated by the fibular nerve) and nerve fragments of approximately $0.5 \mathrm{~cm}$ were collected and identified as described below:

\section{Group G1}

G1TN - tibial nerve cross-section. The fibers were counted to obtain a parameter of normality of the tibial nerve.

G1FN - fibular nerve cross-section. The fibers were counted to obtain a parameter of normality of the fibular nerve.

G1CT - cranial tibial muscle. It was fully collected and weighed on a precision scale to obtain a parameter of normality of the muscle weight.

\section{Group G2}

G2FN - distal stump of the fibular nerve cross-section. The fibers were counted to obtain a denervation parameter of the fibular nerve.

G2PFN - proximal stump of the fibular nerve cross-section. This material was collected to identify the neuroma in the proximal stump of the injured nerve and, thus ruling out the existence of possible reinnervation of the fibular nerve through its proximal stump.

G2CT - cranial tibial muscle. It was fully collected and weighed on a precision scale to obtain a denervation parameter of the muscle weight. 


\section{Group G3}

G3ESN- end-to-side neurorrhaphy cross-section. This material was collected in order to show the nerve sproutings emerging from the donor nerve (n. tibial) to the receptor nerve (n. fibular).

G3FN - distal stump of the fibular nerve cross-section (distal to neurorrhaphy). The fibular nerve fibers were counted and compared with normality, denervation and the latero-lateral loop neurorrhaphy.

G3PFN - proximal stump of the fibular nerve cross-section. This material was collected to identify the neuroma in the proximal stump of the injured nerve and, thus, ruling out the existence of possible reinnervation of the fibular nerve through its proximal stump.

G3TN - tibial nerve cross-section (distal to neurorrhaphy). The material was collected to identify if there was loss of axons of the donor nerve distal to neurorrhaphy, compared to the intact tibial nerve (normal control).

G3CT - cranial tibial muscle. Fully collected and weighed on a precision scale. The weight was compared with the normal group, denervation and latero-lateral loop neurorrhaphy.

\section{Group 4}

G4LLN- latero-lateral loop neurorrhaphy cross-section. This material was collected the in order to show the nerve sproutings emerging from the donor nerve (n. tibial) to the receptor nerve (n. fibular).

G4FN - distal stump of the fibular nerve cross-section (distal to neurorrhaphy). The fibular nerve fibers were counted and compared with normality, denervation and the latero-lateral loop neurorrhaphy.

G4PFN - proximal stump of the fibular nerve cross-section. This material was collected to identify the neuroma in the proximal stump of the injured nerve and, thus, ruling out the existence of possible reinnervation of the fibular nerve through its proximal stump.

G4TN - tibial nerve cross-section (distal to neurorrhaphy). The material was collected to identify if there was loss of axons of the donor nerve distal to neurorrhaphy, compared to the intact tibial nerve (normal control).

G4CT - cranial tibial muscle. Fully collected and weighed on a precision scale. The weight was compared with the normal group, denervation and end-to-side neurorrhaphy.
After removal, the nervous fragments TN, FN and PFN were fixed (in transverse position) in 10\% glutaraldehyde and osmium tetroxide $1 \%$, with inclusion in paraplast, microtome sections with a thickness of $0.5 \mathrm{~mm}$ and toluidine blue staining (Fig. 5). The nerve fragments ESN and LLN were stained with Masson's trichrome and Bielchowiski tecniques.

The cranial tibial muscles were removed and weighed. The weights were compared among the groups. For capturing images and stereological calculations, the microscope and the software Image Pro Plus ${ }^{\circledR}$ version 6.0 were used, with the adoption of Weibel stereological grid ®. We considered the actual distance between the $1 \mu \mathrm{m}$ stitches and 20 microscopic fields per histological slide in order to count the absolute number of stitches on axons, endoneurium and myelin sheath and obtain the arithmetic mean and volume density calculation. The volume density (Vd) was estimated by Chalkley technique (Mandarim-deLacerda, 1995). The Mann-Whitney (U Test) was applied for the statistical analysis, with a $5 \%$ significance level.

\section{RESULTS}

Table I shows the absolute number of axons and the arithmetic mean of the fibular nerve in each group (G1FN, G2FN, and G3FN G4FN). There was a significant reduction in the number of axons in both groups (and G3FN and G4FN) compared to the control group $(\mathrm{p}<0.0001)$.

Table II shows the absolute number of axons and the arithmetic mean of the fibular nerve in each group (G1TN, G2TN, G3TN and G4TN). There was a significant reduction in the number of axons in both groups (and G3TN and G4TN) compared to the control group $(\mathrm{p}<0.0001)$.

Table III shows the volume density (mm2) of axons in each group of the sectioned fibular nerve (G1FN, G3FN and G4FN). Figure 6 shows the arithmetic mean of the volume density in each group of the fibular nerve (G1FN, G3FN, G4FN and denervation group (G2FN)). There was a

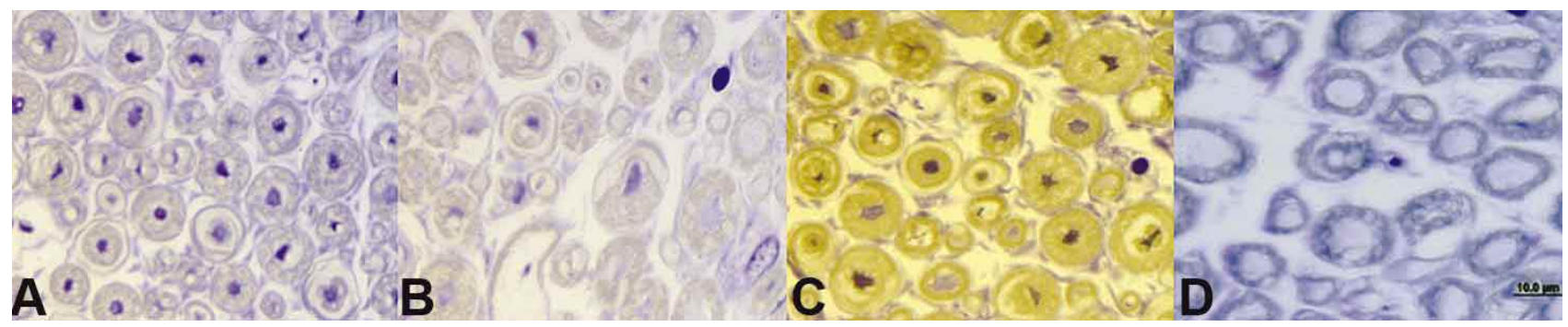

Fig. 5. A to D slide show in korash toluidine blue. A. Normal; B. Neurorraphy side to side; C. Neurorraphy end to side and D. Denervation. 
Table I. The absolute number count and arithmetic mean of axons in each group of sectioned fibular nerve (fibular nerve G1FN= control fibular nerve; G3FN= end-to-side neurorrhaphy with fibular nerve sutured to the tibial nerve; G4FN= loop neurorrhaphy with fibular nerve sutured to the tibial nerve).

\begin{tabular}{lccc}
\hline Rat & G1FN & G3FN & G4FN \\
\hline 1 & 708 & 471 & 368 \\
2 & 590 & 432 & 386 \\
3 & 603 & 403 & 398 \\
4 & 593 & 336 & 431 \\
5 & 607 & 351 & 383 \\
6 & 608 & 445 & 325 \\
7 & 598 & 412 & 412 \\
8 & 615 & 455 & 365 \\
9 & 589 & 402 & 389 \\
10 & 602 & 409 & 414 \\
Arithmetic mean & 611 & 412 & 387 \\
\hline
\end{tabular}

Table II. The absolute number count and arithmetic mean of axons in each group of sectioned tibial nerve $(\mathrm{G} 1 \mathrm{TN}=$ normal tibial nerve; $\mathrm{G} 3 \mathrm{TN}=$ distal tibial nerve to end-to-side neurorrhaphy; G4TN= distal tibial nerve to loop neurorrhaphy).

\begin{tabular}{lccc}
\hline Rat & G1FN & G3FN & G4FN \\
\hline 1 & 0.27 & 0.14 & 0.18 \\
2 & 0.23 & 0.14 & 0.17 \\
3 & 0.23 & 0.14 & 0.16 \\
4 & 0.23 & 0.13 & 0.13 \\
5 & 0.23 & 0.11 & 0.14 \\
6 & 0.23 & 0.13 & 0.17 \\
7 & 0.23 & 0.16 & 0.16 \\
8 & 0.24 & 0.14 & 0.18 \\
9 & 0.23 & 0.15 & 0.15 \\
10 & 0.23 & 0.16 & 0.16 \\
Arithmetic mean & 0.24 & 0.14 & 0.16 \\
\hline
\end{tabular}

Table III. Volume density $\left(\mathrm{mm}^{2}\right)$ and arithmetic mean of axonal volume in each group of sectioned fibular nerve $(\mathrm{G} 1 \mathrm{FN}=$ normal fibular nerve; G3FN= end-to-side neurorrhaphy with fibular nerve sutured to the tibial nerve; G4FN= loop neurorrhaphy with fibular nerve sutured to the tibial nerve).

\begin{tabular}{lccc}
\hline Rat & G1FN & G3FN & G4FN \\
\hline 1 & 0.27 & 0.14 & 0.18 \\
2 & 0.23 & 0.14 & 0.17 \\
3 & 0.23 & 0.14 & 0.16 \\
4 & 0.23 & 0.13 & 0.13 \\
5 & 0.23 & 0.11 & 0.14 \\
6 & 0.23 & 0.13 & 0.17 \\
7 & 0.23 & 0.16 & 0.16 \\
8 & 0.24 & 0.14 & 0.18 \\
9 & 0.23 & 0.15 & 0.15 \\
10 & 0.23 & 0.16 & 0.16 \\
Arithmetic mean & 0.24 & 0.14 & 0.16 \\
\hline
\end{tabular}

Table IV. Volume density and arithmetic mean of axonal volume in each group of sectioned tibial nerve $(\mathrm{G} 1 \mathrm{TN}=$ normal tibial nerve; G3TN = distal tibial nerve to end-to-side neurorrhaphy; G4TN = distal tibial nerve to loop neurorrhaphy).

\begin{tabular}{lccc}
\hline Rat & G1TN & G3TN & G4TN \\
\hline 1 & 0.30 & 0.27 & 0.29 \\
2 & 0.33 & 0.27 & 0.27 \\
3 & 0.28 & 0.24 & 0.27 \\
4 & 0.29 & 0.27 & 0.27 \\
5 & 0.31 & 0.27 & 0.27 \\
6 & 0.29 & 0.27 & 0.27 \\
7 & 0.28 & 0.28 & 0.27 \\
8 & 0.29 & 0.26 & 0.27 \\
9 & 0.30 & 0.27 & 0.27 \\
10 & 0.31 & 0.27 & 0.28 \\
Arithmetic mean & 0.30 & 0.27 & 0.27 \\
\hline
\end{tabular}

significant reduction in the value of the volume density of axons in both groups (G2FN, G3FN, G4FN) in relation to the control group. (p-value $<0.0001)$. Between G3FN and G4FN, there was no significant difference $(p$-value $=0.315)$. There were significant differences between the groups G3FN and G4FN compared to the G2FN denervation.

Table IV and Figure 7 show the absolute values and the arithmetic mean of volume density $\left(\mathrm{mm}^{2}\right)$ of axons in each group of the sectioned tibial

Fig. 6. Average volume density. 


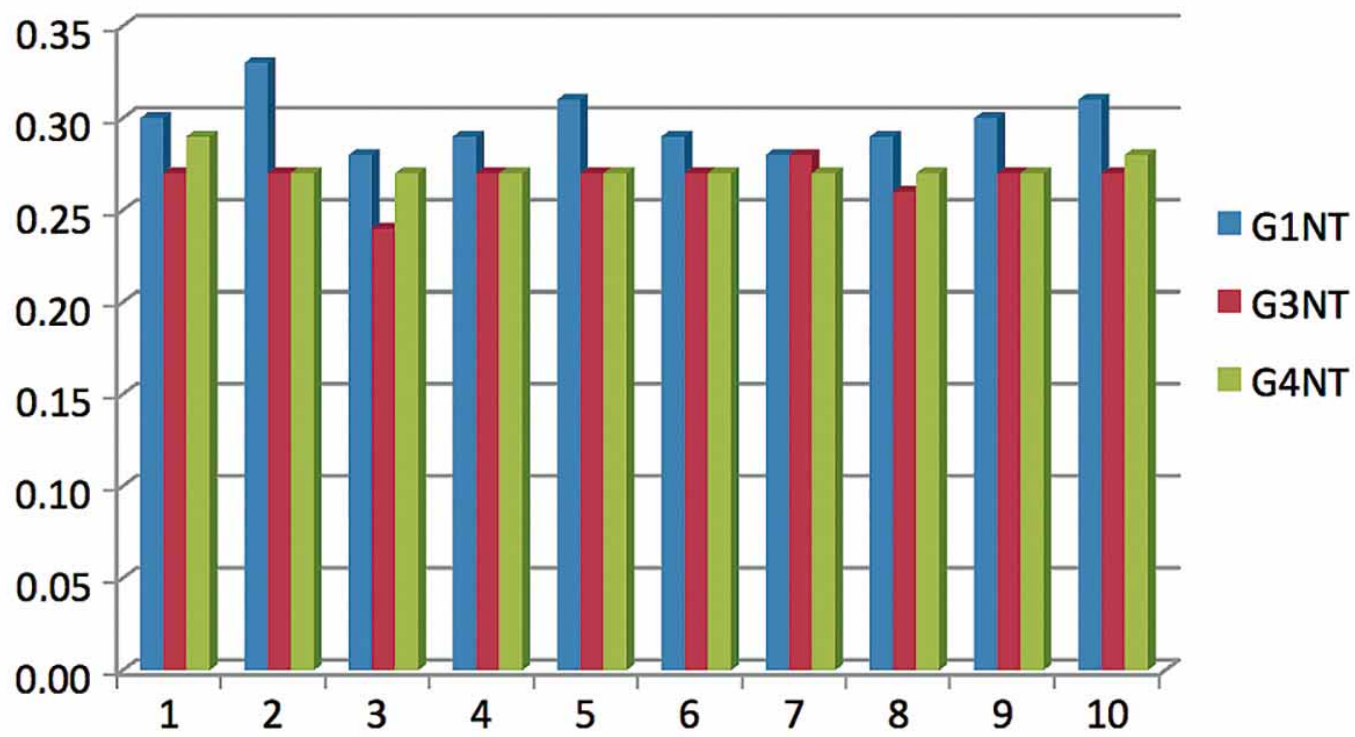

Fig. 7. Volume density of the tibial nerve.

Table V. The weight of the Cranial tibial muscle in each group $(\mathrm{G} 1=$ control group, G2= denervation group; G3= end-to-side group; G4= loop neurorrhaphy group).

\begin{tabular}{cccc}
\hline \multicolumn{4}{c}{ Weight of Cranial tibial muscle in the groups $(\mathbf{g})$} \\
\hline G1 & G2 & $\mathbf{G 3}$ & $\mathbf{G 4}$ \\
\hline 0.8085 & 0.0943 & 0.6924 & 0.7606 \\
1.0021 & 0.1702 & 0.7511 & 0.8700 \\
1.0858 & 0.1112 & 0.6100 & 0.8191 \\
1.1881 & 0.1045 & 0.7708 & 0.5704 \\
1.0665 & 0.0810 & 0.6860 & 0.7281 \\
0.9329 & 0.1372 & 0.7187 & 0.7746 \\
0.9965 & 0.0928 & 0.7341 & 0.6804 \\
1.0352 & 0.1155 & 0.7235 & 0.9636 \\
0.8910 & 0.0952 & 0.3312 & 0.6821 \\
\hline
\end{tabular}

nerve (G1TN, G3TN and G4TN). There was a significant reduction in the value of the volume density of axons in both groups (G3TN and G3TN) in relation to the control group (pvalue $<0.0001)$. Between G3TN and G4TN, despite the value of $(p=0.0147)$, we can not state that the means are significantly different, since all values are close to the 0.27 mean.

Table V shows the weight of the cranial tibial muscle innervated by the fibular nerve in each of the analyzed groups. Significant reduction in the weight values in the groups $(\mathrm{G} 2, \mathrm{G} 3$ and $\mathrm{G} 4)$ in relation to the control group $(\mathrm{G} 1)$ (p-value <0.0001). There was no significant reduction between G3 and G4.

\section{DISCUSSION}

In recent decades, a remarkable increase of molecular, genetic and morphofunctional knowledge of the neuronal regenerative process, as well as technological advances in microsurgery have provided better results in clinical recovery of peripheral nerve injuries (Fu \& Gordon, 1997; Myckatyn \& Mackinnon, 1994). It is known that Schwann cells are responsible for "directing" axon regeneration (Fukuda et al., 1995), release factors that increase the synthesis of nerve growth factor and thus, promote sensorimotor axonal sprouting (Xiong et al., 2003; Hayashi et al., 2004). 
There is the possibility of surgical functional regeneration as long as there is a suture of nerve segment to its trunk, since neurons adjacent to the site of injury secrete substances that contribute to neuronal survival (Da Silva, 1995; Lundborg et al., 1994; Viterbo et al., 1994). Thus, this study proposes a new technique for complete loop neurorrhaphy, and with maximum surface contact of the injured distal stump in relation to the healthy nerve, followed by end-to-side suture. The surgical technique of loop neurorrhaphy is justified for using intact nerve (which "stabilizes" the suture when reducing the local tension (Amr et al.; Xiong et al.) by reducing the intraluminal pressure and allowing neovascularization, axoplasmic flow, cell migration and advance of the axonal growth cone (Kerns et al., 2005).

The end-to-end neurorrhaphies performed in situations, where access to the stumps is difficult, lead to little promising results due to tension in the suture site (Flores; Viterbo et al.; Kerns et al.). On the other hand, laterolateral neurorrhaphies, are not dependent on the distance among stumps, and, have been identified as viable alternatives to nerve grafts (Sanapanich et al., 2002) because they can promote both sensory and motor functional recovery (Xiong et al.). Moreover, in latero-lateral neurorrhaphy, a large number of axonal sprouts may be able to cross the suture area and then promote action of neurotrophic factors essential for the axonal growth, with similar results compared to end-to-side neurorrhaphy (Amr, Xiong et al.).

It is assumed that the technique proposed by this study (or loop neurorrhaphy), direct contact between two nerve promotes greater possibility of action of neurotrophic factors, taking into account the fact that the epineurium is no impediment to axonal regeneration or to passage of the electric stimulus (Viterbo, 1993), since the axoplasmic sproutings are able to cross the epineurium and allow responses in functional tests Lundborg et al. The absence of surgical section of the intact nerve (or donor by contact) minimizes risks related to dysfunction in target tissues, neuronal atrophy or undifferentiated neuroma formation associated with local pain.

In this paper, loop neurorrhaphy was performed in injured fibular nerve and healthy tibial nerves of rats, in order to fit the experimental models that recommend the choice of this animal, because of the possibility of high speed of functional nerve regeneration in short postoperative period, low cost and easy handling. The use of simple points with 10.0 mononylon have shown satisfactory results in peripheral nerve repair (Vasconcelos et al., 2003; Dourado et al., 2003), mainly because there is less secondary tissue damage when reducing the thread caliber in the suture.

Recent studies have indicated that end-to-side loop sutures that increase the contact area between the injured nerves and its receptor provide stability of the joint graft area receptor and function improvement (Viterbo, 2003; Amr et al.; Flores; Kakibushi et al.). In the current study, there is not a statistically significant reduction in the axons volume density after neurorrhaphy (both techniques), and it suggests that end-to-side loop neurorrhaphy can be a viable surgical alternative for peripheral nerve injuries repair.

\section{CONCLUSIONS}

The loop neurorrhaphy or the "closed loop" technique is the surgical reconstruction after neural injury that occurs a complete involvement of the injured nerve trunk, with maximum contact, followed by end-to-side suture. The intact donor nerve is used with local low-tension, and that experimentally it does not cause significant reduction in axons volume density in the injured distal stump, as compared to conventional end-to-side neurorrhaphy. Endto-side loop neurorrhaphy is a therapeutic option as suture technique after complete nerve section, in order to restore most of the axonal functional integrity.

BOER, N. P.; VITERBO, F.; FALEIROS, H. R.; BATIGALIA, F.; BOER, A. L. R.; CARVALHO Jr., A. A. Neurorrafia de blucle terminolateral: estudio axonal estereológico comparativo. Int. J. Morphol., 32(3):942-949, 2014.

RESUMEN: Accidentes o enfermedades pueden afectar a la parte periférica del sistema nervioso, lo que plantea terapias clínicas y quirúrgicas, entre otras. En este contexto, la técnica de neurorrafia término-lateral es una opción terapéutica, sin embargo, su modificación en bucle necesita algunos estudios adicionales de eficacia. El objetivo de este estudio fue comparar, en ratas, resultados estereológicos (densidad de volumen axonal) después de la neurorrafia término-lateral y de la neurorrafia en bucle término-lateral. Fueron utilizadas 30 ratas Wistar, divididas en seis grupos (cinco animales por grupo), siendo dos grupos control (para los nervios fibular y tibial), dos grupos estudio del nervio fibular (uno con neurorrafia término-lateral y otro con neurorrafia en bucle termino-lateral) y dos grupos estudio del nervio tibial (uno con neurorrafia términolateral y otro con neurorrafia en bucle término-lateral). Después de 180 días, todos los grupos fueron eutanasiados y se realizó el análisis estereológico axonal (densidad de volumen) en muñones nerviosos distales. Hubo un mantenimiento significativo de la densidad neuronal-axonal en los muñones distales a la neurorrafia $(\mathrm{p}<0,005)$ en comparación con los muñones normales. La neurorrafia en bucle término-lateral es una opción terapéutica como técnica de sutura después de la sección completa del nervio, con el fin de restaurar la mayoría de la integridad funcional axonal.

PALABRAS CLAVE: Nervio; Axón; Estereología; Neurorrafia. 


\section{REFERENCES}

Amr, S. M.; Moharram, A. N. \& Abdel-Meguid, K. M. Augmentation of partially regenerated nerves by end-to-side side-to-side grafting neurotization: experience based on eight late obstetric brachial plexus cases. J. Brachial Plex. Peripher. Nerve Inj., 1:6, 2006.

Bertelli, J. A. \& Mira, J. C. Nerve repair using freezing and fibrin glue: immediate histologic improvement of axonal coaptation. Microsurgery, 14(2):135-40, 1993.

Calder; J. S. \& Green, C. J. Nerve-muscle sandwich grafts: the importance of Schwann cells in peripheral nerve regeneration through muscle basal lamina conduits. J. Hand. Surg. Br., 20(4):423-8, 1995.

Da Silva, C. F. Biologia celular e molecular da regeneração nervosa do sistema nervoso periférico. Atual. Neuroc., 1(3):1-16, 1995.

Dourado, E.; Gomes, A. C. A.; Gomes, P. F. S. \& Ribeiro, T. P. A. Nervous regeneration technic: cirurgical process and alternatives. Rev. Cir. Traumatol. Buco-Maxilo-Facial, 3(2):49$54,2003$.

Flores, L. P. Neurorrafia término-lateral: uma evolução das técnicas de reparo de nervos periféricos? Arq. Bras. Neurocir., 25(2):66-73, 2006.

Fu, S. Y. \& Gordon, T. The cellular and molecular basis of peripheral nerve regeneration. Mol. Neurobiol., 14(1-2):67-116, 1997.

Fukuda, A.; Hirata, H.; Akeda, K.; Morita, A.; Nagakura, T.; Tsujii, M. \& Uchida, A. Enhanced reinnervation after neurotization with Schwann cell transplantation. Muscle Nerve, 31(2):22934,2005 .

Hata, Y. The real history of end-to-side neurorrhaphy. Br. J. Plast. Surg., 53(7):633-4, 2000.

Hayashi, A.; Yanai, A.; Komuro, Y.; Nishida, M.; Inoue, M. \& Seki, T. Collateral sprouting occurs following end-to-side neurorrhaphy. Plast. Reconstr. Surg., 114(1):129-37, 2004.

Kakibuchi, M.; Tuji, K.; Fukuda, K.; Terada, T.; Yamada, N.; Matsuda, K.; Kawai, K. \& Sakagami, M. End-to-side nerve graft for facial nerve reconstruction. Ann. Plast. Surg., 53(5):496-500, 2004.

Kerns, J. M.; Sladek, E. H.; Malushte, T. S.; Bach, H.; Elhassan, B.; Kitidumrongsook, P.; Kroin, J. S.; Shott, S.; Gantsoudes, G. \& Gonzalez, M. H. End-to-side nerve grafting of the tibial nerve to bridge a neuroma-in-continuity. Microsurgery, 25(2):155-64, 2005.

Lech, O. Princípios básicos. In: Pardini, A. G. Jr. Cirurgia da mão lesão não Traumáticas. Rio de Janeiro, Medsi, 1990. pp.1-33.
Lundborg, G.; Zhao, Q.; Kanje, M.; Danielsen, N. \& Kerns, J. M. Can sensory and motor collateral sprouting be induced from intact peripheral nerve by end-to-side anastomosis? J. Hand. Surg. Br., 19(3):277-82, 1994.

Mandarim-de-Lacerda, C. A. Métodos quantitativos em morfologia. Rio de Janeiro, EdUERJ, 1995. pp.71-109.

Myckatyn, T. M. \& Mackinnon, S. E. A review of research endeavors to optimize peripheral nerve reconstruction. Neurol. Res., 26(2):124-38, 2004.

Sanapanich, K.; Morrison, W. A. \& Messina, A. Physiologic and morphologic aspects of nerve regeneration after end-to-end or end-to-side coaptation in a rat model of brachial plexus injury. J. Hand Surg. Am., 27(1):133-42, 2002.

Vasconcelos, B. C.; Gay Escoda, C.; Vasconcellos, R. J. \& Neves, R. F. Conduction velocity of the rabbit facial nerve: a noninvasive functional evaluation. Pesqui. Odontol. Bras., 17(2):126-31, 2003.

Viterbo, F. A new method for treatment of facial palsy: the crossface nerve transplantation with end-to-side neurorraphy. Rev. Soc. Bras. Cir. Plast. Estet. Reconstr., 8(1-2-3):29-35, 1993.

Viterbo, F. Neurorrafia término-lateral. In: Tatagiba, M.; Mazzer, N.; Aguiar, P. H. P. \& Pereira, C. U. (Eds.). Nervos periféricos. Diagnóstico e tratamento clínico e cirúrgico. Rio de Janeiro, Revinter, 2003. pp.85-7.

Viterbo, F.; Trindade, J. C.; Hoshino K. \& Mazzoni Neto, A. Endto-side neurorrhaphy with removal of the epineurial sheath: an experimental study in rats. Plast. Reconstr. Surg., 94(7):1038-47, 1994.

Xiong, G.; Ling, L.; Nakamura, R. \& Sugiura, Y. Retrograde tracing and electrophysiological findings of collateral sprouting after end-to-side neurorrhaphy. Hand Surg., 8(2):145-50, 2003.

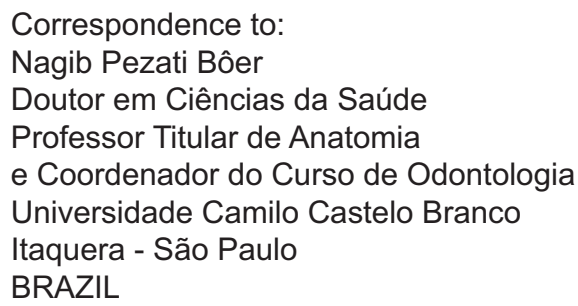

Email: nagib.pezati@terra.com.br

Received: 24-10-2013

Accepted: 28-04-2014 